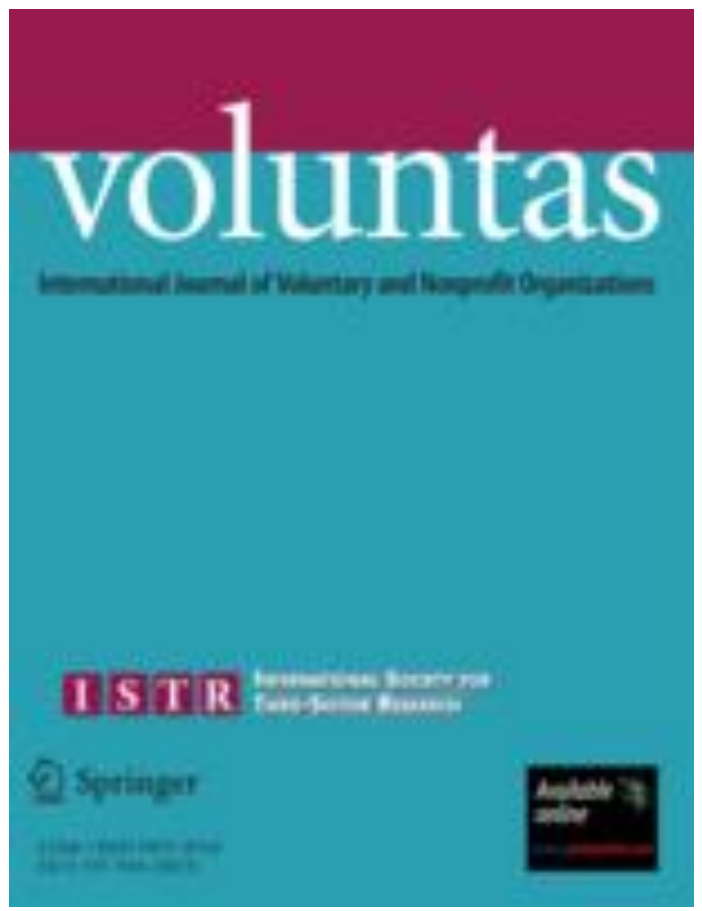

"As accepted for publication in Voluntas: International Journal of Voluntary and Nonprofit Organizations, @Springer"

Christos Anagnostopoulos, (PhD), Molde University College (Norway) and University of Central Lancashire (Cyprus)

Leah Gillooly, (PhD), University of Manchester (UK)

David Cook, (MBA) Coventry University (UK)

Petros Parganas, (DBA), University of Ioannina (Greece)

Simon Chadwick, (PhD), University of Salford (UK) 


\title{
Stakeholder communication in 140 characters or less: A study of community sport foundations
}

\begin{abstract}
Community sport foundations (CSFs), like other non-profit organizations (NPOs), are increasingly employing social media such as Twitter to communicate their mission and activities to their diverse stakeholder groups. However, the way these CSFs utilize social media for communicating such practices remains unclear. Through a mixed-method approach of content analysis of Tweets from 22 CSFs established by English professional football clubs and interviews with key individuals within these CSFs $(n=7)$, this study examines the extent to which CSFs' core activities are being communicated through Twitter and identifies the strategies employed for doing so. Reflecting the target audiences CSFs are seeking to reach through Twitter and the challenges associated with communication about projects involving marginalized groups, tweets largely concern programs related to sports participation and education. The most frequently employed communication strategy is to inform, rather than interact or engage with stakeholders. However, CSFs with higher organizational capacity attempt to go beyond mere informing toward engaging with stakeholder groups that relate to their social agenda, highlighting the importance of trained and dedicated social media personnel in optimizing CSFs' use of Twitter for communication.
\end{abstract}

Keywords: community sport foundations, Twitter communication, CSR, football, stakeholder theory 


\section{Introduction}

Nonprofit organizations (NPOs) generally aim to deliver social and environmental benefits by interacting with a wide range of stakeholders (Van Puyvelde et al. 2012), including those in the commercial (Misener and Doherty 2014), likeminded nonprofit (Shaw and Allen 2006), and public (Walters and Panton 2014) sectors. However, most existing research has agreed that stakeholder communication remains one of the most challenging organizational undertakings within the broad and complex third-sector landscape (Babiak and Thibault 2009; Hayhurst and Frisby 2010; Koschman et al. 2012; Saxton and Guo 2014; Svensson et al. 2015). The challenge in facilitating effective stakeholder communication strategies is evident within the context of community sport foundations (CSFs), which are charitable organizations established by professional sport teams with the aim of utilizing sport as the vehicle for delivering community-based programs (Anagnostopoulos et al. 2014; Bingham and Walters 2013). Such community programs are - by and large - centred on four key areas: encouraging social inclusion, increasing sports participation, promoting a healthy lifestyle and favoring alternative educational methods, which, having sport at their core, aim towards facilitating employment (EFL, 2015; Jenkins and James 2012). Examples include sport and mentoring programs aimed at lowering criminal (re)offending, sports coaching sessions, disability sport programs and physical activity and socializing opportunities for individuals aged 55 years or older. CSFs represent a significant and growing segment of the sport-related non-profit sector, with 97 of 122 US-based professional teams and 89 out of 92 professional football clubs in England having established one (Anagnostopoulos and Shilbury 2013; Sparvero and Kent 2014), While academic 
literature on CSFs is an emerging area (c.f. Misener and Doherty 2014; 2013) given their number and contribution to the sport non-profit landscape (Misener and Babiak 2015), there remains a paucity of research looking at these community-based organizations (Kolyperas et al. 2016).

Consistent with many NPOs, these CSFs face considerable challenges in terms of organizational capacity, that is, their ability to fulfil their mission (Eisinger 2002). Largely dependent on partnerships with statutory agencies and commercial enterprises alike (Bason and Anagnostopoulos 2015; Bingham and Walters 2013; Jamali and Keshishian 2009), CSFs try to enrich the portfolio of social activities that falls under the abovementioned four key themes (i.e., education, health, sports participation and social inclusion) in order to reach out to, and satisfy the various needs of, an increasingly multifaceted stakeholder setting (Walters and Tacon 2010). However, like most NPOs (Balduck et al. 2015; Wicker and Breuer 2013), most CSFs appear to have limited resources and thus lack the capacity for an effective communication strategy to promote the social programs and to demonstrate the impact they have in the local communities (Anagnostopoulos et al. 2014; Jenkins and James 2012; Walters and Chadwick 2009).

As a possible way to cope with such challenges (Curtis et al. 2010), an emerging stream of research is examining how various types of NPOs utilize popular social networking platforms (such as Facebook and Twitter) to communicate with stakeholders in both sports and non-sports contexts (c.f. Auger 2014; Lovejoy and Saxton 2012; Lovejoy et al. 2012; Mamic and Almaraz 2013; Saxton and Guo 2014; Saxton and Waters 2014; Svensson et al. 2015; Svensson and Hambrick 2016; Thompson et al. 2014; Thorpe and Rinehart 2012; Waters and Williams 2011; Waters and Jamal 2011; Waters 
and Feneley 2013). These studies have suggested that social media offer NPOs an unprecedented opportunity to target, mobilize and interact with their stakeholders (Saxton and Guo 2014), and in some cases allows them to engage with stakeholders who can contribute towards organizational capacity-building (for example, potential funders) (Doherty et al. 2014; Misener and Doherty 2009). Thus, given their limited resources (Auger 2014; Bingham and Walters 2013; Svensson et al. 2015), social media is a highly appealing tool for NPOs, including CSFs. However, while social media is a low-cost communications tool (Eagleman 2013; Mamic and Almaraz 2013), its effective use does demand organizational resources of time and money (Nah and Saxton 2012; Waters and Feneley 2013). As such, larger NPOs (or certainly those with greater resources at their disposal) may be better placed (Nah and Saxton 2012) to take full advantage of the benefits in terms of reach (Eagleman 2013) and relationship building (Thorpe and Rinehart 2012).

Studies of the social media activities of large, US-based NPOs dominate the literature on online NPO stakeholder communication (Lovejoy et al. 2012; Lovejoy and Saxton 2012; Saxton and Waters 2014), and while some more recent work has looked at smaller, community-based NPOs (Campbell et al. 2014; Saxton and Guo 2014), literature on sport-related NPO stakeholder communication has concentrated on national governing bodies (NGBs) (Eagleman 2013; Thompson et al. 2014) or the sport-for-development sector (Hambrick and Svensson 2015; Svensson et al. 2015). With sport-related NPOs 'increasingly engaging social media in an effort to understand the needs of and efficiently communicate their programs and services with stakeholders' (Abeza and O'Reilly 2014, p. 128), there is a need for further empirical research in this area. 
Therefore, the principal contribution of this study is to extend existing knowledge of social media communication in the area of NPOs, and, in turn, provide a point of reference for scholars of community-based practices, particularly within the CSF setting. One main goal and two related objectives are forwarded to achieve this contribution. The prime goal is to examine the extent to which core themes of CSFs' social agendas are being communicated through Twitter, as well as the strategies employed for doing so. In addition, drawing on the contextual characteristics and institutional ties these CSFs have with their 'parent' professional teams (Anagnostopoulos and Shilbury 2013; Kolyperas et al. 2016), the study sets out to identify whether different patterns of content distribution by the CSFs emerge during different time periods (i.e. team's on-season versus offseason), as recent studies have suggested (Parganas et al. 2015). Furthermore, given that NPOs' performance (including their ability to effectively communicate and engage with key stakeholders) depends on their overall organizational capacity (Eisinger 2002; Lovejoy et al. 2012; Svensson et al. 2015), the study also examines whether capacity influences both the extent and the type of strategies employed for the communication through Twitter of core social activities delivered by CSFs.

\section{Literature review and theoretical underpinnings}

Organizations in the nonprofit context are founded and controlled primarily by 'demandside stakeholders' (Ben-Ner and Van Hoomissen 1991) - a group of stakeholders that is 'interested in the provision of some services for themselves as consumers and/or for the benefit of others, as donors or sponsors' (Abzug and Webb 1999, p. 416). For CSFs, these demand-side stakeholders comprise both the local community as well as 
government and non-government agencies, local and national businesses and sport governing bodies. The willingness of these demand-side stakeholders to engage in the social initiatives of a CSF is enhanced by their belonging to common groups (that is, supporting the CSF's 'parent' team) and networks (local businesses and statutory agencies). Thus, it becomes imperative for CSFs to strengthen the relationship with these types of stakeholders through continuous communication strategies (Walker et al. 2010). Indeed, the organizational focus has now shifted from just managing multiple and diverse stakeholder groups towards interacting and engaging with specific stakeholders based on a relational view (Andriof and Waddock 2002).

In this pursuit of interaction and engagement, social media, and particularly micro-blogging applications such as Twitter, have the capacity to go beyond a one-way dissemination of social activities, as is the case with other, more 'static', means of communication, such as reports, websites and e-newsletters (e.g., Walker et al. 2010). Consequently, social media can be more efficient in terms of producing intended social outcomes of engaging with stakeholder groups. Moreover, research has shown that social media provides organizations with new directions and benefits in terms of relationshipbuilding (Earnheardt et al. 2012) by offering them a unique environment in which to create brand communities (Habibi et al. 2014; Laroche et al. 2012), conduct marketing research (Poynter 2010), carry out strategic communication campaigns (Waters and Jamal 2011), or even achieve behavioral change (O’Reilly et al. 2012).

Amongst the earliest studies of social media use in the non-profit sector were those of Waters and Jamal (2011) and Waters and Williams (2011), which drew on Grunig and Hunt's (1984) seminal work on the models of PR, applying these to large US- 
based NPOs and government agencies respectively. Despite claims that unidirectional communication by organizations is obsolete in the social media age (Mamic and Alvaraz 2013), both studies found that the NPOs were using largely one-way communications on social media, which is unsurprising considering that many PR messages, particularly of an informational nature, are not naturally dialogic in their orientation (Waters and Jamal 2011; Waters and Williams 2011).

Departing from an inductive approach of categorizing social media posts, Lovejoy and Saxton (2012) categorized the purpose of Tweets by large US NPOs into three communications strategies: information, community and action. Tweets categorized as ‘information' provide news, facts or other information about the NPO and are one-way in nature. In contrast, 'community' Tweets were either interactional in sparking dialogue or fostered relationships with the stakeholder community. Community was thus sub-divided into four categories: 'giving recognition and thanks', 'acknowledgement of current and local events', 'responses to public reply messages', and 'response solicitation'. The final category, 'action', referred to Tweets designed to stimulate followers into taking some form of action. The category was thus sub-divided into the following seven purposes: 'promoting an event', 'donation appeal', 'selling a product', 'call for volunteers and employees', 'lobbying and advocacy', ‘join another site or vote for organization', and 'learn how to help'. As the most comprehensive theoretical framework of NPO stakeholder communication on social media, Lovejoy and Saxton's (2012) work has formed the basis for many subsequent studies across platforms including Facebook (Campbell et al. 2014; Saxton and Waters 2014), Twitter and YouTube (Auger 2013). The use of social media in sport is attracting growing attention from scholars (see 
Abeza et al. (2015) and Filo et al. (2015) for two comprehensive reviews of literature on social media and sport) and in a sports NPO context, several recent studies have adopted a case study approach to examine the implementation and use of social media strategies for NGBs (Thompson et al. 2014) and action sports non-governmental organizations (Thorpe and Rinehart 2012). Taking a wider perspective of US sport NGBs, Eagleman (2013) found - consistent with findings outside the sport context - that these organizations were using social media more for PR and communications purposes, rather than marketing. However, the current study is the first to examine the thematic content of Tweets by CSFs, and to appraise the extent to which these CSFs are using Twitter to communicate their focal mission areas of sports participation, education, health and social inclusion. Therefore, the following research question is proposed:

RQ1: To what extent are the core mission-related themes of CSFs' social agendas being communicated through Twitter?

Building on the literature on social media use by sport NPOs, Svensson et al. (2015) employed Lovejoy and Saxton's (2012) categories to examine the communications strategies employed by sport for development (SFD) organizations on Twitter. These organizations, characterised by a focus on using sport as a vehicle for delivering social change, emphasising issues such as development, peace, conflict resolution and disaster response (Burnett 2009; Svensson et al. 2015), vary considerably in scale, number of focal issues and geographic location. However, consistent with previous studies in the wider non-profit sector, the predominant type of Tweets posted by SFDs was information, followed by community. While no significant difference was found between the number of countries of operation and SFDs' use of Twitter, the geographical 
dispersion and widespread nature of the activities they engage in may lend themselves more to using social media for disseminating information, rather than focusing on the development of community or stimulating action from followers. In contrast, CSFs linked to English football clubs, as the focal point of this study, are much more rooted in their local communities, with their actions being largely geographically concentrated around their home towns/cities (Anagnostopoulos and Shilbury 2013; Roberts et al. 2016), which may impact the ways in which they use Twitter to communicate with stakeholders.

In order to facilitate comparison with previous studies and to extend the literature on the use of Twitter by sport NPOs to the CSF context, the present study uses Lovejoy and Saxton's (2012) three functions (or strategies) of communication on Twitter (information, community, action) as a framework for analyzing the way in which CSFs strategically communicate their initiatives through this social media platform. Thus the following research questions are advanced:

RQ2(a): What communication strategies are used by CSFs on Twitter to communicate their core mission-related themes?

RQ2(b): Are there differences in the communication strategies used to communicate the different mission-related themes?

Given the relationship between CSFs and their 'parent' club and the seasonal nature of the 'parent' club's sporting activities, it is also pertinent to consider whether the communication of different mission-related themes and use of different communication strategies on Twitter differs between the on- and off-season periods, when the focus of the 'parent' club may change. Therefore, the following research questions are advanced: RQ3(a): Are there differences in the core mission-related themes communicated 
by CSFs on Twitter in the on- and off-season periods?

RQ3(b): Are there differences in the communications strategies used by CSFs on Twitter in the on- and off-season periods?

While CSFs form a distinct segment within the wider sport NPO sector, thanks to their unique character of attachment to and dependency on their 'parent' clubs (Kolyperas et al. 2016), they do not represent an entirely homogeneous set of organizations. As outlined above, many CSFs are faced with considerable organizational capacity challenges and are tasked with delivering their mission with varying levels of resource. Organizational capacity, defined by Eisinger (2002, p. 115) as the 'ability of an organization to accomplish its mission effectively', has received considerable academic interest both within and outside of sport (c.f. Doherty et al. 2014; Liket and Maas 2015). Hall et al. (2003) identified three dimensions of organizational capacity in the non-profit sector: financial capacity, human resources capacity and structural capacity. Financial capacity refers to the organization's ability to deploy financial capital; human resources capacity relates to the ability to deploy human capital, including paid and voluntary staff; while structural capacity is divided into relationship and network capacity, infrastructure and process capacity and planning and development capacity (Hall et al. 2003).

The conceptual model of NPO capacity put forward by Hall et al. (2003) has been widely adopted by researchers examining capacity of sports clubs (Balduck et al. 2015; Wicker and Breuer 2013), minor leagues (Sharpe 2006), community sport organizations (Misener and Doherty 2013) and SFDs (Svensson and Hambrick 2016). This latter study was the first in sport to explore the connections between organizational capacity and social media use, building on earlier work on non-sport NPOs (Nah and Saxton 2012). In 
both cases, no relationship was found between organizational capacity and social media use, however capacity in these studies related to financial capacity (and, in the case of Svensson et al. (2015), the number of countries of operation). In the context of social media, where the financial cost is low, it may be the case that usage is constrained more by the availability of skilled human resources (Quinton and Fennemore 2013; Nah and Saxton 2012) and time. Therefore, the following research question is advanced:

RQ4: What impact does organizational capacity have on CSFs use of different communication strategies on Twitter?

Having identified the research questions and theoretical framework to be used to address these questions, the next section will outline the research context and method employed, before the results are presented and discussed.

\section{Method}

Two data collection techniques were employed in this study, namely Twitter content analysis and structured interviews. The fieldwork took place in two different phases, with phase 1 consisting of two sub-phases (on-season and off-season). The first phase involved collecting quantitative data, employing content analysis (Hsieh and Shannon 2005), and using tweets as the unit of analysis (Lin and Peña 2011). Content analysis has

been extensively used in the study of social media both inside (c.f. Abeza et al. 2015; Filo et al. 2015) and outside the sport organization context (e.g., Lin and Peña 2011; Rybalko and Seltzer 2010; Shen and Bissell 2013; Waters and Jamal 2011). However, insights gained from content analysis do not allow for a full examination of CSFs' intended objectives and the challenges they face in executing their Twitter strategies. Thus, phase 
two included structured interviews with personnel within the sampled organizations. The purpose of this phase was to complement the quantitative findings while trying to offer some explanatory insights from key organizational actors.

\section{Sample}

The empirical setting for this study is a set of CSFs that are associated with football clubs from the second tier of English football - the Football League Championship (FLC). The decision to focus on the CSFs of English football, and specifically its second division, was made for two reasons. Firstly, community programs in England through CSFs constitute the strongest institutionalized form of corporate social responsibility (CSR) delivery across European professional team sport organizations (Hovemann et al. 2011; Kolyperas and Sparks 2011; Walters and Tacon 2010). Secondly, scholars seem to favor 'top flight' leagues such as the Premier League (PL) for the examination of various business-related activities; thus, very little is known about the operations of lower-ranked football clubs (Bruns et al. 2014; Emery and Weed 2006). Moreover, local embeddedness of these football clubs and their geographic scope that is, arguably, more concentrated than the one of 'top-flight' teams, necessitates greater communication with local stakeholders.

\section{Data collection and analyses}

Twitter content. In order to collect Twitter data on CSFs, we examined the official websites of all 24 FLC clubs in the 2014-2015 season, to identify: (a) whether these clubs have established an independent CSF for the delivery of community programs, and (b) whether those established CSFs have their own Twitter accounts. This search revealed that 22 clubs had CSFs that use dedicated Twitter accounts to communicate their 
community programs.

Quantitative data were collected in two phases. Given the close ties these CSFs have with their 'parent' football clubs, they tend to generate and communicate Twitter content that relates to the club's activities, such as the team's results, player transfer announcements, updates on players' physical condition, and so forth (Parganas et al. 2015), and not necessarily to the main aims of the CSFs themselves (e.g., Lovejoy et al. 2012; Svensson et al. 2015). Such content is much more frequent during the on-season which in England typically runs from August until May - when the 'parent' football club has playing duties. Therefore, on-season Twitter data was collected from a period working back from $3^{\text {rd }}$ April, 2015 during March and April 2015, while off-season data were gathered three months later, after the playing season ended, from a period working back from $3^{\text {rd }}$ July 2015 (June/July, 2015). This resulted in on-season data being collected for the majority of clubs (19 out of 22) in March and April 2015, and off-season data being collected in June and July 2015. The CSF of Bolton Wanderers FC (@OfficialBWCT), was a notable exception, tweeting at a much lower frequency than the other sampled CSFs. Therefore, its data collection periods ran from December to April 2015 for on-season, and April to July 2015 for off-season respectively. As a result, five of the sampled off season tweets for @ OfficialBWCT were actually collected during the onseason. Whilst unavoidable in our case and therefore representing a limitation of the study, these Tweets accounted for only $0.2 \%$ of the total sample.

A non-random sample (Marshall 1996; Stavros et al. 2014) of the last 50 tweets per period per CSF ( $n=2,200$ tweets in total) was taken. Tweets were copied from the Twitter feed of the CSF and stored in Microsoft Excel, and subsequently manually coded, 
as detailed in the following section. Our analysis of the total number of tweets sent by each CSF revealed a median of 2,271, which served as a guidance for our sample. This sample size is also in line with that of Lovejoy and Saxton's (2012) study on NPOs' use of Twitter $(n=2,437)$. However, it is worth noting that this is in contrast to previous studies that were limited to an off-season examination of social media content by professional sport organizations (e.g., Meng et al. 2015; Stavros et al. 2014). The dataset used reduces the possibility for bias relating to specific time frames (Watanabe et al. 2016), thereby offering a better representation of how the CSFs utilise Twitter.

The content analysis used both deductive and inductive reasoning in two main stages. Firstly, a coding sheet was developed based on four broad themes, namely, sports participation, education, health and social inclusion, which are, in essence, 'missionrelated' themes. These were taken from the 2013/14 Annual Report of the Football League Trust, a national charity to which all CSFs with a non-PL status are accountable. Details of these themes are provided in Table 1. In order to examine the degree to which the core social agenda of these CSFs is communicated to stakeholders, each tweet was coded manually based on its content, and was then allocated to one of the four themes. However, during the first stage of this coding process it became evident that some tweets could not be allocated to any of the themes. Consequently, a more inductive approach was adopted, resulting in the formation of three additional ('non mission-related') themes, namely parent club, commercial and other. 
Table 1: Coding frame for CSFs' Tweet themes

\begin{tabular}{|c|c|c|}
\hline Theme & Description & Example Tweets \\
\hline Sports participation & $\begin{array}{l}\text { Tweets concerning } \\
\text { programmes with a focus } \\
\text { on increasing participation } \\
\text { in sport among all age and } \\
\text { ability groups. }\end{array}$ & $\begin{array}{l}\text { "Have you booked your place at one of } \\
\text { our three easter camps yet? Find out } \\
\text { more and book via } \\
\text { http://laticscommunity.org! \#wafc" }\end{array}$ \\
\hline Education & $\begin{array}{l}\text { Tweets concerning } \\
\text { programmes focused } \\
\text { around education (at all } \\
\text { levels). }\end{array}$ & $\begin{array}{l}\text { "What an amazing group of young } \\
\text { people!Dragons den presentations to } 5 \\
\text { different charities! @ NCS \#future } \\
\text { @NCSFLT" }\end{array}$ \\
\hline Health & $\begin{array}{l}\text { Tweets concerning } \\
\text { programmes focused on } \\
\text { improving the health of } \\
\text { local communities. }\end{array}$ & $\begin{array}{l}\text { "We have launched a new skin cancer } \\
\text { awareness campaign. Please do take a } \\
\text { few minutes to read up about it: } \\
\text { http://albioninthecommunity.org.uk/new } \\
\text { s/skin-cancer-awareness-campaign- } \\
\text { launched ..." }\end{array}$ \\
\hline Social inclusion & $\begin{array}{l}\text { Tweets concerning } \\
\text { programmes focused on } \\
\text { tackling disadvantage and } \\
\text { promoting equality. }\end{array}$ & $\begin{array}{l}\text { "The great Millers youth forum standing } \\
\text { together against hate crime in Rotherham } \\
\text { \#WeStandTogether \#bowling" }\end{array}$ \\
\hline Parent club & $\begin{array}{l}\text { Tweets that are related } \\
\text { purely to football clubs' } \\
\text { operations }\end{array}$ & $\begin{array}{l}\text { "FIRST DAY BACK! It's the first day of } \\
\text { pre-season training at Sparrows Lane } \\
\text { today. \#cafc" }\end{array}$ \\
\hline Commercial & $\begin{array}{l}\text { Tweets related to the } \\
\text { CSF's business affairs }\end{array}$ & $\begin{array}{l}\text { "Does your Son or Daughter have a } \\
\text { birthday coming up? Celebrate with us! } \\
\text { For more info: } \\
\text { http://www.nottinghamforestinthecomm } \\
\text { unity.co.uk/birthday-packages/ ..." }\end{array}$ \\
\hline Other & $\begin{array}{l}\text { Tweets that do not fit } \\
\text { neatly into any of the other } \\
\text { six themes }\end{array}$ & $\begin{array}{l}\text { "Come on England Lionesses we are } \\
\text { right behind you!!!! England Women's } \\
\text { World Cup semi-final v Japan. KO } \\
\text { Midnight. http://bbc.in/1NtaSxJ" }\end{array}$ \\
\hline
\end{tabular}

The second stage of the content analysis entailed categorizing the Tweets into the three strategies of Twitter communication - information, community and action (Lovejoy and Saxton 2012). While Lovejoy and Saxton (2012) further sub-divide their categories (see above discussion), in this study we focus on the higher level codes of information, community and action. The predominantly local nature of CSFs' activities renders some 
of Lovejoy and Saxton's (2012) sub-categories, such as lobbying and advocacy, irrelevant in this context. Equally, the focus of the current study is more concerned with the overall use of the different communication strategies across mission-related themes, differing levels of OC and time-periods. As such, it was felt that making such finely-grained subdivisions within the communication strategies would not add significantly to the overall findings and may indeed render comparisons difficult due to potentially small sample sizes within cross-tabulations. Details of these categories are provided below in Table 2. On completion of the second stage of the coding process, inter-coder reliability (Neuendorf 2002) was calculated using Cohen's kappa (Lombard et al. 2002), with acceptable scores achieved for both stages of the coding process (themes $\pi=0.78$ and strategies $\pi=0.91)$. 
Table 2: Coding frame for communication strategies

\begin{tabular}{|c|c|c|}
\hline Category & Description & Example Tweets \\
\hline Information & $\begin{array}{l}\text { Tweets which aim to notify } \\
\text { stakeholders about CSFs' } \\
\text { programmes. This entails one-way } \\
\text { communication with Twitter } \\
\text { followers, which seeks neither } \\
\text { interaction nor engagement. }\end{array}$ & $\begin{array}{l}\text { "The winners of the girls tournament } \\
\text { were @langleyschool @FLT_FFD } \\
\text { @BirminghamFA" }\end{array}$ \\
\hline Community & $\begin{array}{l}\text { Tweets geared towards two-way } \\
\text { exchanges, with a focus on fostering } \\
\text { relationships and promoting } \\
\text { interactivity. Through this strategy, } \\
\text { CSFs largely react and respond to } \\
\text { questions or observations made by } \\
\text { followers regarding community- } \\
\text { related programmes, without trying to } \\
\text { proactively interact or engage with } \\
\text { followers about the organizations' } \\
\text { community initiatives. }\end{array}$ & $\begin{array}{l}\text { "hi @worthinghour - We've launched } \\
\text { our \#southdowns \#sussex walk - } 7 \text { or } \\
25 \text { miles to raise funds for disability } \\
\text { sports! } \\
\text { https://www.facebook.com/events/13 } \\
81913862128035 / . . . "\end{array}$ \\
\hline Action & $\begin{array}{l}\text { Tweets which place more emphasis } \\
\text { on disseminating information in a way } \\
\text { that promotes or asks stakeholders to } \\
\text { 'contribute' towards certain } \\
\text { programmes initiated by the CSF (in } \\
\text { the form of donating, volunteering, } \\
\text { attending events etc.) }\end{array}$ & $\begin{array}{l}\text { "Who's joining us at @GoFestUK 10- } \\
12 \text { July? We're hosting a range of } \\
\text { sessions ages 5-16+. Visit } \\
\text { http://gofest.co.uk to register today!" }\end{array}$ \\
\hline
\end{tabular}

Following coding, the frequencies of the items (that is, 'themes' and 'strategies') were calculated and descriptive statistics and chi-square tests were performed in SPSS 19 to determine any associations between the variables, with a Bonferroni correction used to reduce the probability of obtaining Type I errors (Beasley and Schumacker 1995; GarciaPerez and Nunez-Anton 2003) and Cramer's V correlation ( $\Phi)$ used to determine the strength of the associations.

The starting point for the statistical analysis was to divide the 22 CSFs according to their organizational capacity (OC) (see Table 3). Drawing on Eisinger's (2002) study on nonprofit charitable organizations, which defined capacity as 'a set of attributes that 
help or enable an organization to fulfil its missions' (p. 117), the two most pertinent OCrelated dimensions were used: financial capacity and human resources. When considering the use of social media, the infrastructure required to create and maintain a Twitter presence is minimal, requiring simply an Internet connection and an Internet-enabled PC, laptop or mobile device. Therefore, differences in capacity of CSFs relating to their use of social media are likely to concern differences in financial and human resources capital. However, it is acknowledged that differences may exist between CSFs in the relationship and network and planning and development capacity areas and therefore the extension of this study to explore additional measures of OC is advocated below in the section on limitations and areas for future research.

In concentrating on financial and human resources capacity, OC was calculated by dividing each CSF's total income by its number of employees, here called the efficiency ratio. The median of this efficiency ratio was then used to split the CSFs into two categories - low organizational capacity (LOC), consisting of CSFs with OC below the median, and high organizational capacity (HOC), consisting of CSFs with OC above the median. These two categories thus each contained 1100 Tweets (50 on-season and 50 off-season Tweets for 11 CSFs). Data on the two dimensions of the OC were collected and cross-checked from two independent web sources (www.endole.co.uk and www.gov.uk). Total income of the CSFs ranged from $£ 532,030.00$ to $£ 4,846.48$ (M = $1,307.95 ; \mathrm{SD}=1,020.54)$, while the number of employees ranged from 18 to $91(\mathrm{M}=$ 37.09, $\mathrm{SD}=19.02)$ 
Table 3: Details of CSFs' Twitter activity and OC

\begin{tabular}{|c|c|c|c|c|c|c|c|}
\hline \multirow[b]{2}{*}{ Community Sport Foundation (CSF) of: } & \multirow[b]{2}{*}{$\begin{array}{l}\text { Joined } \\
\text { Twitter }\end{array}$} & \multirow[b]{2}{*}{$\begin{array}{c}\text { Total Number } \\
\text { of Tweets }\end{array}$} & \multirow[b]{2}{*}{ Following } & \multirow[b]{2}{*}{ Followers } & \multicolumn{3}{|c|}{ Organisational Capacity } \\
\hline & & & & & $\begin{array}{c}\text { Total } \\
\text { Income } \\
\text { (£000) }\end{array}$ & Employees & $\begin{array}{l}\text { Efficiency } \\
\text { ratio }\end{array}$ \\
\hline Birmingham City FC (@BCFC_Community) & Sept 2012 & 1915 & 694 & 1887 & 631,85 & 22 & 28,72 \\
\hline Blackburn Rovers FC (@BRFCTRUST) & Dec 2009 & 954 & 1287 & 1834 & 638,98 & 19 & 33,63 \\
\hline Blackpool FC (@BFC_CTrust) & Feb 2011 & 1122 & 446 & 1161 & 532,89 & 23 & 23,17 \\
\hline Bolton Wanderers FC (@OfficialBWCT) & Not stated & 749 & 246 & 766 & 717,37 & 20 & 35,87 \\
\hline Bournemouth FC (@AFCBCommunity) & Oct 2011 & 6096 & 1767 & 2560 & 532,03 & 18 & 29,56 \\
\hline Brentford FCb(@BrentfordFCCST) & Dec 2010 & 3566 & 1730 & 2047 & 1245,90 & 29 & 42,96 \\
\hline $\begin{array}{l}\text { Brighton and Hove Albion FC } \\
\text { (@albioninthecomm) }\end{array}$ & Aug 2011 & 1841 & 1212 & 2719 & 3064,89 & 60 & 51,08 \\
\hline Cardiff City FC (@CardiffCityFITC) & Nov 2011 & 4029 & 507 & 4266 & 1649,34 & 58 & 28,44 \\
\hline Charlton Athletic FC (@CAFCTrust) & Dec 2009 & 1997 & 337 & 1808 & 4846,48 & 91 & 53,26 \\
\hline Derby County FC (@DCCTOfficial) & Dec 2010 & 2208 & 199 & 1703 & 1401,58 & 37 & 37,88 \\
\hline Fulham FC (@FulhamFCFound) & Not stated & 591 & 268 & 896 & 1739,63 & 45 & 38,66 \\
\hline Huddersfield Town FC (@thezonehet) & Jan 2012 & 3094 & 1620 & 1098 & 1373,62 & 69 & 19,91 \\
\hline Leeds United FC (@LUFCFoundation) & Not stated & 368 & 223 & 1249 & 812,08 & 20 & 40,60 \\
\hline Middlesbrough FC (@MFCFoundation) & Feb 2013 & 1887 & 362 & 2180 & 1213,72 & 26 & 46,68 \\
\hline Millwall FC (@Millwall_MCT) & Oct 2011 & 2574 & 501 & 2733 & 741,56 & 29 & 25,57 \\
\hline Norwich City FC (@NorwichCityCSF) & Nov 2011 & 3831 & 326 & 4759 & 2366,42 & 52 & 45,51 \\
\hline $\begin{array}{l}\text { Nottingham Forest FC } \\
\text { (@NFFC_Community) }\end{array}$ & Feb 2012 & 1714 & 570 & 4114 & 538,42 & 32 & 16,83 \\
\hline Rotherham FC (@RU_CST) & Aug 2011 & 3756 & 1221 & 1578 & 810,73 & 22 & 36,85 \\
\hline Sheffield Wednesday FC (@SWFCCP) & Jun 2013 & 429 & 412 & 1290 & 1031,32 & 39 & 26,44 \\
\hline Watford FC (@WFCTrust) & Mar 2011 & 2927 & 230 & 1580 & 1542,67 & 33 & 46,75 \\
\hline Wigan FC (@LaticsCommunity) & Not stated & 1573 & 183 & 867 & 746,06 & 46 & 16,22 \\
\hline $\begin{array}{l}\text { Wolverhampton Wanderers FC } \\
\text { (@wolvescomtrust) }\end{array}$ & Jan 2011 & 2750 & 379 & 2493 & 597,35 & 26 & 22,98 \\
\hline \multicolumn{2}{|l|}{$M=$} & 2271,41 & 669,09 & 2072,18 & 1307,95 & 37,09 & 33,98 \\
\hline \multicolumn{2}{|l|}{$S D=$} & 1414,37 & 534,19 & 1110,07 & 1020,54 & 19,02 & 11,01 \\
\hline
\end{tabular}

Semi-structured interviews. In line with the four main research questions of this study, we formulated four specific interview questions (see Appendix). Guided by the quantitative results, purposive sampling was used to target specific individuals within the 22 sampled CSFs. What is important in purposive sampling is not the actual number of cases or participants, but as Taylor and Bogdan (1984) assert, 'the potential of each 'case' to aid the researcher in developing theoretical insights into the area of social life being studied' (p. 83). Thus, on the basis of critical cases (Creswell 1998), the official websites of all 22 CSFs were visited in order to identify those individuals who deal with 
communication, marketing and/or the strategic development of the CSF. Then, the lead author used a professional online social network to initially contact these employees in order to establish the necessary professional rapport. Subsequently, on the $25^{\text {th }}$ July 2016 , an email was sent to 22 key organizational actors asking them to answer the four questions. In total, seven interviews were conducted by the first and second author during July/August 2016 (see Table 4). Despite the low return, the sample provided a balanced mixture of OC status as it consisted of three representatives of CSFs with high OC, and four with low OC.

Table 4: Interview details

\begin{tabular}{|c|c|c|c|c|}
\hline Interviewee & Job title & $\begin{array}{c}\text { Date of } \\
\text { interview }\end{array}$ & $\begin{array}{l}\text { Interview } \\
\text { method }\end{array}$ & $\begin{array}{l}\text { Organization's } \\
\text { efficiency ratio }\end{array}$ \\
\hline CSF1 & $\begin{array}{c}\text { Head of } \\
\text { Development }\end{array}$ & 25 July 2016 & email & High \\
\hline CSF2 & $\begin{array}{l}\text { Community } \\
\text { Development } \\
\text { Manager }\end{array}$ & 26 July 2016 & email & High \\
\hline CSF3 & $\begin{array}{c}\text { Marketing \& } \\
\text { Communications } \\
\text { Officer }\end{array}$ & 27 July 2016 & Phone & High \\
\hline CSF4 & $\begin{array}{c}\text { Director of Sport \& } \\
\text { Health }\end{array}$ & 25 July 2016 & Phone & Low \\
\hline CSF5 & $\begin{array}{c}\text { Marketing \& } \\
\text { Communications } \\
\text { Officer }\end{array}$ & 28 July 2016 & email & Low \\
\hline CSF6 & $\begin{array}{c}\text { Communications } \\
\text { Officer }\end{array}$ & $\begin{array}{l}8 \text { August } \\
2016\end{array}$ & Phone & Low \\
\hline CSF7 & $\begin{array}{c}\text { Media Events \& } \\
\text { Motivate! } \\
\text { Coordinator }\end{array}$ & $\begin{array}{l}23 \text { August } \\
2016\end{array}$ & email & Low \\
\hline
\end{tabular}

Interview data was analysed thematically, with the main goal being that of 'thick description' (Pratt 2009) of the findings in the form of 'data extracts' that could complement and, ideally offer explanatory insights of, the findings of the content analysis. All interviewees were guaranteed anonymity and therefore interview transcripts were assigned numbers that correlated to each interview (e.g., CSF1). The numeral 
indicates the specific participant, recognisable only to themselves and the authors.

\section{Results and Discussion}

\section{Communication of core mission-related themes}

An overview of the themes communicated in the posts of the CSFs is presented in Table 5. In response to RQ1, we can see that $71 \%$ of the tweets posted by CSFs relate to one of the four mission-related themes of sports participation, education, health and social inclusion.

Table 5: Communication of themes

\begin{tabular}{|l|l|l|}
\hline Theme & Frequency of Tweets & Percentage \\
\hline Education & 420 & $19.1 \%$ \\
\hline Health & 88 & $4.0 \%$ \\
\hline Social inclusion & 214 & $9.7 \%$ \\
\hline Participation & 845 & $38.4 \%$ \\
\hline Commercial & 71 & $3.2 \%$ \\
\hline Parent club & 222 & $10.1 \%$ \\
\hline Other & 340 & $15.5 \%$ \\
\hline
\end{tabular}

Therefore, it would appear that these CSFs have a reasonably strong focus on their core mission areas within their stakeholder communications on Twitter. Of these, two themes dominated the Twitter communications from CSFs, with $57 \%$ of the tweets studied concerned with community programs in sports participation (38\%) and education (19\%). There may be several reasons for this finding, which reflect the ever-increasing emphasis that both governmental agencies in the UK and NPOs place on these two social issues. First of all, there is evidence that highlights a substantial decrease in sports participation after young people leave school, with football in particular reaching as high as a $32 \%$ dropout rate for 11-to-16-year-olds (Taylor, 2011). As such, the CSFs' focus on sports participation can be seen as a response to the UK government's 2012 Olympic 
Legacy plans (DCMS, 2012) and vision for physical education and school sports as an attempt to reverse this decline and encourage lifelong participation in sporting activities among a broader base of young people. The relevance of Twitter to this younger demographic, who represent the main target for sports participation and education programs, was also identified by CSF5 as a reason for the predominance of these themes in CSFs' Twitter posts. As sports participation and educational programs are frequently delivered in parallel (for example, through 'summer schools'), these often constitute the prime revenue streams for CSFs (Jenkins and James 2012) outside the funding that comes from sport governing bodies and statutory organizations. Therefore, targeting pertinent communications to stakeholder groups that contribute towards revenue generation, and consequently ensure the viability of these CSFs, may go a long way towards explaining why Twitter content focuses on these themes.

On the flip side, the interviews revealed that gathering tangible evidence around health-related programs takes a long time, which can delay CSFs ability to discuss this theme (CSF1). Similarly, communications related to social inclusion "need to be very well planned," as "public pronouncements can unintentionally subordinate these groups and communities even more, hence the infrequencies of these [themes in our Twitter content]" (CSF1). In many cases, CSFs would have to gain the permission of participants (or their guardians) to use their image in any photographs posted on Twitter and this can prove problematic, reducing the ability of CSFs to post about social inclusion and health programs (CSF7). Therefore, it appears that the communication of core mission-related themes is both driven by external priorities and constrained by the sensitive nature of some of these themes. 
In contrast, only $10 \%$ of tweets focused on the activities of the 'parent' football club, and 3\% were commercially related tweets. The lack of linkage back to the 'parent' club in CSFs' Twitter communications might be considered a missed opportunity. For example, the sample has provided no evidence to 'link' any of the community themes with the 'parent' club's operations. Indeed, one interviewee identified the blending of CSF and 'parent' club content as a particular challenge:

The main issue is that we have such a variety of service users, that we are constantly aware of using the right tone and not alienating some people - in other words, our charity has so many different facets in the community that it is difficult to represent them in a single social media voice. (CSF4)

However, closer cooperation between the two entities may facilitate a type of 'multipurpose' Twitter content. Such multi-purpose tweets can have the CSFs' social agenda at their core and, at the same time, promote the products/services of the 'parent' football club.

What is also striking is the fact that the third highest percentage of the Twitter content could not be neatly assigned to any of the pre-determined or inductively emergent theme-based categories. Previous research (Etter 2014; O'Reilly et al. 2012; Waters and Jamal 2011) has underlined the importance of tailor-made social media content with the purpose of satisfying specific organizational objectives, not least in the nonprofit sector where resources are scarce (Balduck et al. 2015; Bingham and Walters 2013; Misener and Doherty 2009; Saxton and Guo 2014; Wicker and Breuer 2013). Therefore, Twitter content that does not explicitly relate to any (or even to a combination) of the themes these CSFs engage with has fewer opportunities to be 'taken forward' by the relevant stakeholder groups. If that is the case, then its impact is minimal and the benefits this 
particular social medium as a whole offers remain largely unexploited (Guo and Saxton 2014; Svensson et al. 2015).

Table 6 below identifies the overall frequencies with which the different communications strategies were employed by CSFs (RQ2a), while Table 7 breaks down the usage of the three strategies for communicating each of the CSFs' mission- and nonmission-related themes (RQ2b).

Table 6: Use of communication strategies

\begin{tabular}{|c|c|c|}
\hline $\begin{array}{c}\text { Communication } \\
\text { Strategy }\end{array}$ & $\begin{array}{c}\text { Frequency of } \\
\text { Tweets }\end{array}$ & Percentage \\
\hline Information & 1164 & $52.9 \%$ \\
\hline Community & 433 & $19.7 \%$ \\
\hline Action & 603 & $27.4 \%$ \\
\hline
\end{tabular}

Table 7: Communication of themes by strategy

\begin{tabular}{|c|c|c|c|c|c|c|c|}
\hline & Education & Health & $\begin{array}{l}\text { Social } \\
\text { inclusion }\end{array}$ & Participation & Commercial & $\begin{array}{l}\text { Parent } \\
\text { club }\end{array}$ & Other \\
\hline $\begin{array}{l}\text { Information } \\
\% \text { within } \\
\text { theme }\end{array}$ & $\begin{array}{l}257 \\
61.2 \%\end{array}$ & $\begin{array}{l}44 \\
50.0 \%\end{array}$ & $\begin{array}{l}72 \\
33.6 \%\end{array}$ & $\begin{array}{l}498 \\
58.9 \%\end{array}$ & $\begin{array}{l}31 \\
43.7 \%\end{array}$ & $\begin{array}{l}98 \\
44.1 \%\end{array}$ & $\begin{array}{l}164 \\
48.2 \%\end{array}$ \\
\hline $\begin{array}{l}\text { Community } \\
\% \text { within } \\
\text { theme }\end{array}$ & $\begin{array}{l}59 \\
14.0 \%\end{array}$ & $\begin{array}{l}17 \\
19.3 \%\end{array}$ & $\begin{array}{l}41 \\
19.2 \%\end{array}$ & $\begin{array}{l}149 \\
17.6 \%\end{array}$ & $\begin{array}{l}8 \\
11.3 \%\end{array}$ & $\begin{array}{l}77 \\
34.7 \%\end{array}$ & $\begin{array}{l}82 \\
24.1 \%\end{array}$ \\
\hline $\begin{array}{l}\text { Action } \\
\% \text { within } \\
\text { theme }\end{array}$ & $\begin{array}{l}104 \\
24.8 \%\end{array}$ & $\begin{array}{l}28 \\
31.8 \%\end{array}$ & $\begin{array}{l}101 \\
47.2 \%\end{array}$ & $\begin{array}{l}198 \\
23.4 \%\end{array}$ & $\begin{array}{l}32 \\
45.1 \%\end{array}$ & $\begin{array}{l}47 \\
21.2 \%\end{array}$ & $\begin{array}{l}94 \\
27.6 \%\end{array}$ \\
\hline
\end{tabular}

Consistent with previous research that has examined the way Twitter is used for communication in both the nonprofit (Auger 2014; Guo and Saxton 2014; Svensson et al. 2015) and commercial (Etter 2014) sectors, the information category accounted for the largest share of tweets by CSFs in our study (53\%). Although there is a recognition that some time is still needed before a more sophisticated use of this social medium is achieved (e.g. "it's a learning curve as still a relatively new concept, learning how to use 
it properly..." (CSF4)), the primary goal for these CSFs remains to establish themselves as one of the most influential social agencies in the local community. The extract below demonstrates just that:

Our ultimate vision is to be the most recognisable charity in our region, so it follows that we would use Twitter, in the first instance, to let people know we exist! We hope to continue to build our profile, raise awareness, and increase participation in our projects. Having said that, user interaction is an area we hope to always build on, to give our charity a personality and a profile. (CSF5)

The next most frequently used communications strategy among CSFs was action (27\%), with tweets adopting a community strategy accounting for only $20 \%$ of the sample. One possible reason for the number of action posts is that the provision of a range of events, programs and initiatives lies at the heart of the core activities of many CSFs (Bingham and Walters 2013; Kolyperas et al. 2016). Given their often limited resources, CSFs may choose to direct their social media energies towards those tweets which are likely to drive participation in such activities, hence the popularity of action tweets. As one of the interviewees characteristically explains:

Once we inform people we then interact and engage with them at the events themselves. Action comes at the sessions themselves, we inform people about details such as age groups, disabilities, etc. Everyone knows what is going on and then at the events we obviously try to engage with them. (CSF6)

In contrast, unlike some larger (Auger 2013; Nah and Saxton 2012; Saxton and Waters 2014), or development-oriented (Svensson et al. 2015), NPOs, CSFs may be less concerned with fostering relations with the community via Twitter, perhaps as their more local nature facilitates a greater degree of offline relationship building than is possible on 
a larger scale.

When examining the different themes of the CSFs' tweets, we found a strong association between the information strategy and the themes education (61\% of tweets relating to education were of the 'information' kind) and sports participation (59\% of sports participation tweets were informational). Clearly, the short-form communication style of Twitter facilitates the dissemination of information about CSFs' programs and activities to a wide range of stakeholders and this finding echoes previous work which emphasized the prevalence of one-way, informational communication strategies by NPOs on Twitter (Hambrick and Svensson 2015; Nah and Saxton 2012; Saxton and Waters 2014).

In contrast, CSFs are using the action communication strategy more for tweets relating to social inclusion (47\%) and commercial activities (45\%). One explanation for the greater degree of action tweets relating to social inclusion is that through their social inclusion programs, CSFs work with "a range of marginalized groups" (CSF1) thus the more targeted communication of this theme, around specific events or initiatives, rather than the more general, information-type Tweets, may prove beneficial.

While the largest percentage of tweets relating to the parent club were informational (44\%), it is notable that $35 \%$ of 'parent' club-related tweets fitted the community communication strategy, the highest of all themes using this strategy. The relatively large number of tweets relating to the parent club that fitted within the community communication strategy might suggest that, rather than engaging in dialogue around their core mission-related themes, CSFs are more comfortable in engaging with stakeholders via Twitter around club-related issues. Where CSFs reported attempts to use 
a community strategy to communicate their core mission-related themes, this was curtailed as a result of derogatory responses received:

We have published, for example, tweets about the ladies' team or our down syndrome team, asked people to engage, and the comments/RTs etc. have been to

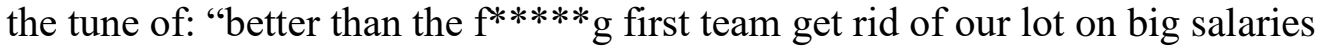
and get these dopes in"! We've had to take content down for this. Instead, CSFs will tend to wait for good news and positive results and get engagement out on the back of those. (CSF1)

Thus, CSFs may feel constrained in their ability to employ community communication strategies in order to protect their diverse range of interest and user groups and consequently their online reputations.

Communication in the on- and of-season periods

In response to RQ3a, during the on-season, CSFs' themes fell mainly into the categories of sports participation (38\%) and education (21\%) (see Table 8 below for full details). A total of 155 tweets (14\%) were regarded as other. The findings are largely similar during the off-season, where the CSFs' themes were again mainly about sports participation (39\%), followed by education (17\%), while $17 \%$ of the sampled tweets were regarded as other. 
Table 8: Communication of themes in on- and off-season periods

\begin{tabular}{|l|l|l|}
\hline Theme & On-season & Off-season \\
\hline Education & 227 & 193 \\
\% within time period & $20.6 \%$ & $17.5 \%$ \\
\hline Health & 37 & 51 \\
\% within time period & $3.4 \%$ & $4.6 \%$ \\
\hline Social inclusion & 122 & 92 \\
\% within time period & $11.1 \%$ & $8.4 \%$ \\
\hline Sports participation & 414 & 431 \\
\% within time period & $37.6 \%$ & $39.2 \%$ \\
\hline Parent club & 122 & 100 \\
\% within time period & $11.1 \%$ & $9.1 \%$ \\
\hline Commercial & 23 & 48 \\
\% within time period & $2.1 \%$ & $4.4 \%$ \\
\hline Other & 155 & 185 \\
\% within time period & $14.1 \%$ & $16.8 \%$ \\
\hline Total & 1100 & 1100 \\
\hline
\end{tabular}

During the on-season, a common pattern emerged for all CSFs, with most tweets allocated to the information strategy, followed by action and then community. The results were very similar during off-season (see Table 9) (RQ3b). However, the present study found evidence that the action strategy is used more during the off-season, when CSFs are less inclined to use the information strategy, and are more focused on posting tweets with the aim of engaging stakeholders. This trend towards greater use of the action strategy during the off-season was explained by CSF4, who suggested at that quiet time on the sporting front "the off-season presents opportunity to engage with people by offering our projects as an alternative to the club and football, as opposed to a subsidiary." 
Table 9: Communication strategies employed in on- and off-season periods

\begin{tabular}{|l|l|l|}
\hline $\begin{array}{l}\text { Communication } \\
\text { Strategy }\end{array}$ & On-Season & Off-Season \\
\hline $\begin{array}{l}\text { Information } \\
\text { \% within time } \\
\text { period }\end{array}$ & $\begin{array}{l}599 \\
54.5 \%\end{array}$ & $\begin{array}{l}565 \\
51.4 \%\end{array}$ \\
\hline $\begin{array}{l}\text { Community } \\
\text { \% within time } \\
\text { period }\end{array}$ & $\begin{array}{l}217 \\
19.7 \%\end{array}$ & $\begin{array}{l}216 \\
19.6 \%\end{array}$ \\
\hline $\begin{array}{l}\text { Action } \\
\text { \% within time } \\
\text { period }\end{array}$ & 284 & $\begin{array}{l}319 \\
29.0 \%\end{array}$ \\
\hline
\end{tabular}

In contrast to the off-season, where no significant relationship between communication strategies and themes was observed $\left(\chi^{2}(12, n=1100)=20.372, p=\right.$ 0.06), statistical results for the on-season period revealed a significant and strong association between the communication strategies and the themes $\left(\chi^{2}(12, n=1100)=\right.$ 149.135, $p<0.001, \Phi=0.26)$. In particular, measuring against the Bonferroni corrected $p$ value $\left(p_{\mathrm{adj}}=0.0023\right)$, in the on-season, the statistical analysis pointed to a strong positive association between: (a) the information strategy and the themes sports participation and education; (b) the community strategy and the theme parent club; and (c) the action strategy and the theme social inclusion. Our findings thus support previous contentions that Twitter communications produced by sports organizations differ between on- and off-season periods (Parganas et al. 2015).

Association between $O C$ and Communication Strategies

An overview of the communication strategies used by high- and low-OC CSFs, addressing RQ4, is presented in Table 10. 
Table 10: Communication strategies used by high- and low-organizational capacity CSFs

\begin{tabular}{|c|c|c|c|c|c|c|c|}
\hline \multirow{2}{*}{\multicolumn{2}{|c|}{$\begin{array}{c}\text { Organizational } \\
\text { Capacity }\end{array}$}} & \multicolumn{6}{|c|}{ Communication Strategy } \\
\hline & & \multicolumn{2}{|c|}{ Information } & \multicolumn{2}{|c|}{ Community } & \multicolumn{2}{|c|}{ Action } \\
\hline & & On-season & Off-season & On-season & Off-season & $\begin{array}{c}\text { On- } \\
\text { season }\end{array}$ & Off-season \\
\hline \multirow[t]{2}{*}{ LOC } & Frequency & 358 & 323 & 86 & 99 & 106 & 128 \\
\hline & $\begin{array}{ll}\% & \text { within } \\
\text { LOC } & \end{array}$ & $65,1 \%$ & $58,7 \%$ & $15,6 \%$ & $18 \%$ & $19,3 \%$ & $23,3 \%$ \\
\hline \multirow[t]{2}{*}{ HOC } & Frequency & 241 & 242 & 131 & 117 & 178 & 191 \\
\hline & $\begin{array}{ll}\% & \text { within } \\
\text { HOC } & \end{array}$ & $43,8 \%$ & $44,0 \%$ & $23,8 \%$ & $21,3 \%$ & $32,4 \%$ & $34,7 \%$ \\
\hline \multirow[t]{2}{*}{ Total } & Frequency & 599 & 565 & 217 & 216 & 284 & 319 \\
\hline & $\%$ & $54,5 \%$ & $51,4 \%$ & $19,7 \%$ & $19,6 \%$ & $25,8 \%$ & $29 \%$ \\
\hline
\end{tabular}

Statistical tests revealed a significant association between the OC of CSFs and their employed communication strategies in both on-season $\left(\chi^{2}(2, n=1100)=50.438, p\right.$ $<0.001, \Phi=0.214)$ and off-season $\left(\chi^{2}(2, n=1100)=25.554, p<0.001, \Phi=0.15\right)$. In particular, LOC CSFs tend to generate mainly information-related content, whereas CSFs with HOC employ the other two strategies much more frequently. More specifically, the study's findings indicate that HOC CSFs use the action strategy more frequently (approximately 33\% of tweets across both the on-season and the off-season for HOC, compared with approximately $21 \%$ for LOC). Several HOC CSFs reported having a "full-time marketing and communications officer," which has resulted in "a large increase in [their] post reach and follower growth on Twitter" (CSF3). Having such dedicated support may explain why certain CSFs (specifically those with HOC) go beyond just information-related communication.

Therefore, it seems that additional resources (for example, staff) enable use of a communication strategy that facilitates greater engagement between CSFs and various stakeholder groups (Jenkins and James 2012). Here, we see a departure in our findings from those of Svensson and Hambrick (2016), who found no association between OC and social media use. Given that the costs associated with social media use are often more in 
time than money (Quinton and Fennemore 2013; Nah and Saxton 2012), the inclusion of human resource capacity in our study may account for these differences. Indeed, although CSFs' representatives acknowledge how user-friendly and uncostly a tool Twitter is (e.g., "one of the main benefits to Twitter, we feel, is that it is free to use" (CSF4)), at the same time CSFs, with LOC in particular, admit that in terms of "directly investing resources into Twitter, we have gone no further at this stage" (CSF2), while others are reliant on several members of staff to create Twitter content alongside their day-to-day roles (CSF7). However, there is evidence from the interviews that several LOC CSFs are cognizant of the need to invest in resources, both physical (e.g., cameras) and human to bolster their ability to deliver a wide range of post types and thereby reap greater social or business benefits from their Twitter use. Thus, the present study supports previous assertions that NPOs wishing to maximise the benefits of social media outlets should post well thought-through content from trained professionals (Quinton and Fennemore 2013; Svensson et al. 2015), which coheres with their organizational priorities.

\section{Practical implications}

Drawing on the study's results, we identify three managerial implications that are relevant to NPOs in general, and CSFs in particular. Firstly, the communication imbalance between the core mission-related themes supports the need for administrative personnel within these NPOs to align their social objectives more closely with their communication activities. Tailoring Twitter content to address specific social issues that are relevant to, and appropriate for, (all) existing or potential partners can either strengthen or initiate such relationships and partnerships. 
Secondly, and building on the above-mentioned implication, our study serves to highlight the apparent missed opportunity of 'multi-purpose' communication, wherein a number of different themes are covered within the same tweet. Such multi-purpose tweets may offer the opportunity to engage with several instrumental stakeholder groups simultaneously (including the 'parent' football club), leading to a more efficient, and even savvier, approach by CSFs to their communication strategies. Again, well-trained administrative personnel will be needed for this, since the approach requires not only communication skills, but also a solid awareness of the CSF's social agenda through its entire partnership portfolio, as well as the 'parent' club's commercial affairs, to ensure that potential conflicts and tensions between stakeholders can be avoided.

Thirdly, from a revenue generation perspective, the volume of commercially themed tweets was found to be relatively low. On the one hand, this could be positively received in terms of CSFs appearing to look 'genuine'; that is, getting across the message that a charitable organization is not being used as a vehicle for commercial purposes. However, on the other hand, it can also constitute a developmental area wherein CSFs can become more commercially savvy not only to fulfil their funding obligations, but also to demonstrate their revenue-generation capabilities to the 'parent' football club. This, in turn, can attract additional 'buy-in' from the latter organization, thereby potentially facilitating a more coordinated social media communication strategy between and across the two organizations.

\section{Limitations and future research}

The contributions of this study should be understood in light of its limitations, which, in 
turn, offer avenues for future research. Firstly, the geographical context in which the study was carried out could have impacted the inferences drawn. CSFs in England are becoming increasingly professionalized, which means that the present findings cannot necessarily be generalized to CSFs in other countries. For that reason, in order to achieve greater generalizability and increase confidence in the findings, the current research should be replicated and validated using samples from different geographical settings.

There are also limitations at the methodological level. Specifically, the deductive analysis conducted through the adoption of categories from the Football League Trust Annual Report generated coding challenges in the sense that categories were often not sufficiently discrete and the list of categories was non-exhaustive. Saxton and Guo (2014) faced similar difficulties in their coding process relating to stakeholder theory, and for this reason the current study also employed inductive reasoning, which allowed the emergence of two key categories (namely, commercial and parent club) with some potentially useful practical implications. As such, further qualitative research might offer a richer account of contextual factors that may have a bearing on the way in which NPOs use Twitter. Moreover, the study's content analysis, while conducted during the same period for all CSFs, may be subject to limitations because CSFs that had joined Twitter at a comparatively early stage may have gained considerably more experience on the use of this medium than those that had joined later. Furthermore, a sample of 50 tweets per CSF, per period, may indicate potential bias in the sense that a series of tweets may be focused on a particular theme, such as an educational program or a health initiative. Therefore, future research employing a greater breadth of sample, both in terms of volume of tweets and time period, is encouraged. 
In relation to $\mathrm{OC}$, this study focused on financial and human resources capacity to differentiate between CSFs. However, OC is a multidimensional construct, comprising other elements, notably structural capacity (Hall et al. 2003), which might have a bearing on CSFs' ability to both leverage relationships with external technical and marketing partners and develop and carry out effective social media plans and strategies. Therefore, the findings relating to $\mathrm{OC}$ must be viewed in this context and future research, involving primary research with CSFs to assess OC more holistically (e.g., CSFs attached to professional teams with higher league status) will make a valuable extension to the results presented here.

Finally, future research should extend the findings of this study by looking at whether and how social media usage can be (or has been) converted into more tangible resources (for example, fostering additional funding, increasing numbers of program participants, amplifying partnership portfolios and so on).

\section{Conclusion}

The central purpose of this study was to examine the extent to which core themes of CSFs' social agendas are being communicated through Twitter within the English football industry, and the strategies employed for doing so. This is the first study to empirically show how this social medium is being utilized by this particular type of NPO. The findings suggest that these CSFs are creating content on Twitter by largely drawing on two themes ('sports participation' and 'education'), while much of such Twitter content falls outside their broader social portfolio (that is, categorised as 'other'). Consistent with findings from other NPO contexts, for CSFs, information remains the 
most frequently employed communication strategy, although notable differences in strategy were identified across core mission-related and non-mission-related (e.g., 'parent' club) themes. Furthermore, in contrast to previous work, the present study empirically shows that CSFs' organizational capacity impacts their Twitter content, with lower capacity CSFs producing a predominance of informational content, while CSFs with greater capacity have been able to devote more resource to their social media activities and thus engage in a broader range of communication strategies.

While offering this initial account of how CSFs communicate their activities through Twitter, caution is required in suggesting that more interaction or engagement will increase the value of these community programs. Rather, we highlight the degree to which these foundations communicate progressive programs in their quest to reach various stakeholder groups through an increasingly popular social medium. More research is needed in order to better understand what this social medium can offer these NPOs, which are often forced to strike a balance between social and business logic. We hope that the present study helps to provide a foundation that will facilitate this line of study. 


\section{References}

Abeza, G., \& O'Reilly, N. (2014). Social media platforms' use in building stakeholder relationships. Journal of Applied Sport Management, 6(3), 103-126.

Abeza, G., O’Reilly, N., Séguin, B., \& Nzindukiyimana, O. (2015). Social media scholarship in sport management research: A critical review. Journal of Sport Management, 29(6), 601-618.

Abzug, R., \& Webb, J.N. (1999). Relationships between nonprofit and for-profit organizations: A stakeholder perspective. Nonprofit and Voluntary Sector Quarterly, 28(4), 416-431.

Andriof, J., \& Waddock, S. (2002). Unfolding stakeholder engagement. In Andriof, J., Waddock, S., Husted, B. and Rahman, S.S. (Eds.), Unfolding Stakeholder Thinking: Theory, Responsibility and Engagement (pp. 19-42). Sheffield: Greenleaf.

Anagnostopoulos, C., \& Kolyperas, D. (2015). Corporate social responsibility of and through sport. In T. Byers (Ed.) Contemporary issues in sport management (pp. 473-486). London: Sage.

Anagnostopoulos, C., Byers, T., \& Shilbury, D. (2014). Corporate social responsibility in professional team sport organizations: towards a theory of decision-making. European Sport Management Quarterly, 14(3), 259-281.

Anagnostopoulos, C., \& Shilbury, D. (2013). Implementing corporate social responsibility in English football: Towards multi-theoretical integration. Sport, Business, and Management: An International Journal, 3(4), 268-284.

Auger, A.G. (2014). Rhetorical framing: examining the message structure of nonprofit organizations on Twitter. International Journal of Nonprofit and Voluntary Sector Marketing, 19, 239-249.

Auger, G.A. (2013) Fostering democracy through social media: Evaluating diametrically opposed non-profit advocacy organizations' use of Facebook, Twitter and YouTube. Public Relations Review 39(4), 369-376.

Babiak, K., \& Thibault, L. (2009). Challenges in multiple cross-sector partnerships. Nonprofit and Voluntary Sector Quarterly, 38(1), 117-143.

Balduck, A.L., Lucidarme, S., Marlier, M., \& Willem, A. (2015). Organizational capacity and organizational ambition in nonprofit and voluntary sports clubs. VOLUNTAS: International Journal of Voluntary and Nonprofit Organizations, 26(5), 2023-2043.

Bason, T., \& Anagnostopoulos, C. (2015). Corporate social responsibility through sport: a longitudinal study of the FTSE100 companies. Sport, Business and Management: An International Journal, 5(3), 218-241.

Beasley, T. M., \& Schumacker, R. E. (1995). Multiple regression approach to analyzing contingency tables: Post hoc and planned comparison procedures. The Journal of Experimental Education, 64(1), 79-93.

Ben-Ner, A., \& Van Hoomissen, T. (1991). Nonprofits in the mixed economy: A demand and supply analysis. Annals of Public and Cooperative Economics 62(4), 519-550.

Bingham, T., \& Walters, G. (2013). Financial sustainability within UK charities: Community sport trusts and corporate social responsibility partnerships. VOLUNTAS: International Journal of Voluntary and Nonprofit Organizations 24(3), 606-629. 
Bruns, A., Weller, K., \& Harrington, S. (2014). Twitter and sports: Football fandom in emerging and established markets. In Weller, K., Bruns, A., Burgess, J., Mahrt, M., \& Puschmann, C. (Eds.) Twitter and Society. Peter Lang, New York, pp. 263-280.

Burnett, C. (2009). Engaging sport-for-development for social impact in the South African context. Sport in Society 12, 1192-1205.

Campbell, D.A., Lambright, K.T. and Wells, C.J. (2014) Looking for friends, fans and followers? Social media use in public and nonprofit human services. Public Administration Review 74(5), 655-663.

Creswell, J. (1998). Qualitative inquiry and research design. Choosing among five traditions. London: Sage Publications.

Curtis, L., Edwards, C., Fraser, K.L., Gudelsky, S., Holmquist, J., Thornton, K. and Sweetser, K.D. (2010) Adoption of social media for public relations by non-profit organizations. Public Relations Review 36(1), 90-92.

DCMS. (2012) Plans for the legacy from the 2012 Olympic and Paralympic Games. Available at: https://www.gov.uk/government/publications/plans-for-the-legacyfrom-the-2012-olympic-and-paralympic-games [Accessed 27 July 2016]

Doherty, A., Misener, K., \& Cuskelly, G., (2014) Toward a multidimensional framework of capacity in community sport clubs. Nonprofit and Voluntary Sector Quarterly 43(2), 124S-142S.

Eagleman, A.N. (2013) Acceptance, motivations, and usage of social media as a marketing communications tool amongst employees of sport national governing bodies. Sport Management Review 16(4), 488-497.

EFL. (2015) Football League Trust Annual Report. Available at: http://www.efl.com/global/trustannualreport.aspx [Accessed 1 July 2016]

Earnheardt, A. C., Haridakis, P., \& Hugenberg, B. (2012) Sports fans, identity and socialization: Exploring the fandemonium. Lexington Books, UK.

Emery, R., \& Weed, M. (2006) Fighting for survival? The financial management of football clubs outside the 'top flight' in England. Managing Leisure 11(1), 1-21.

Eisinger, P. (2002) Organizational capacity and organizational effectiveness among streetlevel food assistance programs. Nonprofit and Voluntary Sector Quarterly 31(1), $115-130$.

Etter, M. (2014) Broadcasting, reacting, engaging - three strategies for CSR communication in Twitter. Journal of Communication Management 18(4), 322342.

Filo, K., Lock, D., \& Karg, A. (2015) Sport and social media research: A review. Sport Management Review 18(2), 166-181.

Football League Trust (2015) Tackling society's greater goals. Available at: http://www.football-league.co.uk/documents/flt-annual-report-201314-final041214549-2123850.pdf - accessed 5 May 2015.

Garcia-Perez, M. A., \& Nunez-Anton, V. (2003) Cellwise residual analysis in two-way contingency tables. Educational and Psychological Measurement 63(5), 825-839.

Grunig, J.E., \& Hunt, T. (1984). Managing public relations. CBS College Publishing, New York, NY.

Guo, C., \& Saxton, D. G. (2014) Tweeting social change: How social media are changing nonprofit advocacy. Nonprofit and Voluntary Sector Quarterly 43(1), 57-79.

Habibi, M.R., Laroche, M., \& Richard, M.O. (2014) The roles of brand community and 
community engagement in building brand trust on social media. Computers in Human Behavior 37, 152-161.

Hall, M. Andrukow, A., Barr, C., Brock, K., de Wit, M., Embuldeniya, D., Jolin, L., Lasby, D., Lévesque, B., Malinsky, E., Stowe, S. and Vaillancourt, Y. (2003) The capacity to serve. A qualitative study of the challenges facing Canada's nonprofit and voluntary organizations. Toronto: Canadian Centre for Philanthropy.

Hambrick, E. M. and Svensson, G. P. (2015) Gainline Africa: A case study of sport-fordevelopment organizations and the role of organizational relationship building via social media. International Journal of Sport Communication 8(2), 233-254.

Hayhurst, L., \& Frisby, W. (2010) Inevitable tensions: Swiss and Canadian sport for development NGO perspectives on partnerships with high performance sport. European Sport Management Quarterly 10(1), 75-96.

Hsieh, H.F., \& Shannon, E.S. (2005) Three approaches to qualitative content analysis. Qualitative Health Research 15(9), 1277-1288.

Hovemann, G., Breitbarth, T., \& Walzel, S. (2011) Beyond sponsorship? Corporate social responsibility in English, German and Swiss top national league football clubs. Journal of Sponsorship 4, 338-352.

Jamali, D., \& Keshishian, T. (2009) Uneasy alliances: Lessons learned from partnerships between businesses and NGOs in the context of CSR. Journal of Business Ethics 84(2), 277-295.

Jenkins, H., \& James, L. (2012) It's not just a game: community work in the UK football industry and approaches to corporate social responsibility. The ESRC Centre for business relationship, accountability, sustainability and society, Cardiff University.

Kolyperas, D., Anagnostopoulos, C., Chadwick, S., \& Sparks, L. (2016) "Applying a Communicating Vessels Framework to CSR Value Co-creation: Empirical Evidence from Professional Team Sport Organizations." Journal of Sport Management, doi: 10.1123/jsm.2016-0032

Kolyperas, D., \& Sparks, L. (2011) Corporate social responsibility communications in the G-25 football clubs. International Journal of Sport Management and Marketing 10(1/2), 83-103.

Koschmann, A.M., Kuhn, T., \& Pfarrer, D.M. (2012) A communicative framework of value in cross-sector partnerships. Academy of Management Review 37(3), 332354.

Laroche, M., Habibi, M.R., Richard, M.O., \& Sankaranarayanan, R. (2012) The effects of social media based brand communities on brand community markers, value creation practices, brand trust and brand loyalty. Computers in Human Behavior 28(5), 1755-1767.

Lombard, M., Snyder-Duch, J., \& Bracken, C. (2002) Content analysis in mass communication: Assessment and reporting of intercoder reliability. Human Communication Research 28(4), 587-604.

Lovejoy K., \& Saxton, G.D. (2012) Information, community, and action: How nonprofit organizations use social media. Journal of Computer-Mediated Communication 17(3), 337-353.

Lovejoy, K., Waters. R.D., \& Saxton, G.D. (2012) Engaging stakeholders through Twitter: How nonprofit organizations are getting more out of 140 characters or less. Public Relations Review 38(2), 313-318. 
Liket, C.K., \& Maas, K. (2015) Nonprofit organizational effectiveness analysis of best practices. Nonprofit and Voluntary Sector Quarterly 44(2), 268-296.

Lin, S.J., \& Peña, J. (2011) Are you following me? A content analysis of TV networks' brand communication on twitter. Journal of Interactive Advertising 12(1), 17-29.

Mamic, L.I. and Almaraz, I.A. (2013) How the larger corporations engage with stakeholders through Twitter. International Journal of Market Research 55(6), 851872.

Marshall, M. (1996) Sampling for qualitative research. Family Practice 13(6), 522-525.

Meng, M.D., Stavros, C., \& Westberg, K. (2015) Engaging fans through social media: implications for team identification". Sport, Business and Management: An International Journal 5(3), 199-217.

Misener, K., \& Babiak, K. (2015) A new 'arena': Social responsibility through nonprofit community sport. Paper presented at the North American Society for Sport Management Conference, June 2-6, Ottawa, Canada.

Misener, K., \& Doherty, A. (2014) In support of sport: Examining the relationship between community sport organizations and sponsors. Sport Management Review 17(4), 493-506.

Misener, K. and Doherty, A. (2013) Understanding capacity through the processes and outcomes of interorganizational relationships in nonprofit community sport organizations. Sport Management Review 16(2), 135-147.

Misener, K., \& Doherty, A. (2009) A case of organizational capacity in nonprofit community sport. Journal of Sport Management 23(4), 457-482.

Morsing, M. and Schultz, M., \& Nielsen, U. (2008) The 'catch-22' of communicating CSR: Findings from a Danish study. Journal of Marketing Communications 14(2), 97-111.

Nah, S. and Saxton, G.D. (2012) Modeling the adoption and use of social media by nonprofit organizations. New Media \& Society 15(2), 294-313.

Neuendorf, K. A. (2002). The content analysis guidebook. New York (NY): Sage.

O'Reilly, N., Berger, I., Hernandez, T., Parent, M., \& Sequin, B. (2012) Understanding adolescent sport participation through online social media. Sport, Business and Management: An International Journal 2(1), 69-81.

Parganas, P., Anagnostopoulos, C., \& Chadwick, S. (2015) "You'll never tweet alone": Managing sports brands through social media. Journal of Brand Management 22(7), 552-568.

Poynter, R. (2010). The handbook of online social media research: Tools and techniques for market researchers. UK: Wiley.

Pratt, M. (2009) For the lack of a boilerplate: tips on writing up (and reviewing) qualitative research. Academy of Management Journal 52(5), 856-862.

Quinton, S., \& Fennemore, P. (2013). Missing a strategic marketing trick? The use of online social networks by UK charities. International Journal of Nonprofit and Voluntary Sector Marketing 18(1), 36-51.

Roberts, A., Roche, N., Jones, C., \& Munday, M. (2016) What is the value of a Premier League football club to a regional economy? European Sport Management Quarterly, online first: DOI:10.1080/16184742.2016.1188840

Rybalko, S., \& Seltzer, T. (2010) Dialogic communication in 140 characters or less: how fortune 500 companies engage stakeholders using twitter. Public Relations Review 
36(4), 336-341.

Saxton, G.D., \& Guo, C. (2014) Online stakeholder targeting and the acquisition of social media capital. International Journal of Nonprofit and Voluntary Sector Marketing 19(4), 286-300.

Saxton, G.D. and Waters, R.D. (2014) What do Stakeholders Like on Facebook? Examining Public Reactions to Nonprofit Organizations' Informational, Promotional, and Community-Building Messages. Journal of Public Relations Research 26(3), 280-299

Sharpe, E.K. (2006) Resources at the Grassroots of Recreation: Organizational Capacity and Quality of Experience in a Community Sport Organization. Leisure Sciences 28(4), 385-401

Shaw, S., \& Allen, J. (2006) "It basically is a fairly loose arrangement ... and that works out fine, really." Analysing the dynamics of an inter-organizational partnership. Sport Management Review 9(3), 203-228.

Shen, B., \& Bissell, K. (2015) "Social Media, Social Me: A Content Analysis of Beauty Companies' Use of Facebook in Marketing and Branding." Journal of Promotion Management, 19(5), 629-651.

Sparvero, E., \& Kent, A. (2014) "Sport Team Nonprofit Organizations: Are Sports Doing Well at" Doing Good"?” Journal of Applied Sport Management 6(4).

Stavros, C., Meng, M.D., Westberg, K., \& Farrelly, F. (2014) Understanding fan motivation for interacting on social media. Sport Management Review 17(4), 455469.

Svensson, P.G. and Hambrick, M.E. (2016) "Pick and choose our battles" Understanding organizational capacity in a sport for development and peace organization. Sport Management Review 19(2), 120-132

Svensson, G. P., Mahoney, Q. T., \& Hambrick, E. M. (2015) Twitter as a communication tool for nonprofits: A study of sport-for-development organizations. Nonprofit and Voluntary Sector Quarterly 44(6), 1086-1106.

Taylor, P. (2011) Torkildsen's Sport and leisure management. (6 $6^{\text {th }}$ ed.). Oxon: Routledge.

Taylor, S.J., \& Bogdan, R. (1984) Introduction to qualitative research methods: The search for meanings. New York, NY: John Wiley.

Thompson, A-J., Martin, A.J., Gee, S. and Eagleman, A.N. (2014) Examining the development of a social media strategy for a national sport organisation. Journal of Applied Sport Management 6(2), 42-63

Thorpe, H. and Rinehart, R. (2012) Action sport NGOs in a neo-liberal context: The cases of Skateistan and Surf Aid International. Journal of Sport and Social Issues 37(2), 115-141

Van Puyvelde, S., Caers, R., Du Bois, C., \& Jegers, M. (2012) The governance of nonprofit organizations: Integrating agency theory with stakeholder and stewardship theories. Nonprofit and Voluntary Sector Quarterly 41(3), 431-451.

Walker, M., Kent, A., \& Vincent, J. (2010) Communicating socially responsible initiatives: An analysis of US professional teams. Sport Marketing Quarterly 19(4), 187-195.

Walters, G., \& Panton, M. (2014). Corporate social responsibility in professional football. Soccer and Society 15(6), 828-846.

Walters, G., \& Chadwick, S. (2009) Corporate citizenship in football: delivering strategic benefits through stakeholder engagement. Management Decision 47(1), 51-66. 
Walters, G., \& Tacon, R. (2010) Corporate social responsibility in sport: Stakeholder management in the UK football industry. Journal of Management and Organisation 14(4), 566-586.

Watanabe, N., Yan, G., \& Soebbing, P. (2016) Major league baseball and Twitter usage: The economics of social media use. Journal of Sport Management 30(2), 207-220.

Waters, R.D., \& Jamal, J.Y. (2011) Tweet, tweet, tweet: A content analysis of nonprofit organizations' Twitter updates. Public Relations Review 37(3), 321-324.

Waters, R.D., \& Feneley, K.L.B. (2013) Virtual stewardship in the age of new media: have nonprofit organizations' moved beyond Web 1.0 strategies? International Journal of Nonprofit and Voluntary Sector Marketing 18(3), 216-230.

Waters, R.D., \& Williams, J. M. (2011) Squawking, tweeting, cooing, and hooting: analyzing the communication patterns of government agencies on Twitter. Journal of Public Affairs 11(4), 353-363.

Wicker, P., \& Breuer, C. (2013) Understanding the importance of organizational resources to explain organizational problems: Evidence from nonprofit sport clubs in Germany. VOLUNTAS: International Journal of Voluntary and Nonprofit Organizations 24(2), 461-484. 